DOI: 10.17707/AgricultForest.65.1.10

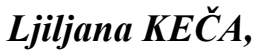 Aleksandar MARKOVIĆ ${ }^{1}$
}

\section{PAYMENTS FOR ECOSYSTEM SERVICES AND STAKEHOLDER'S PERSPECTIVES IN SERBIA}

\begin{abstract}
SUMMARY
Payments for environmental services (PES) have attracted increasing interest as a mechanism to translate non-market values of the environment, into real financial incentives for local actors to provide environmental services. The PES concept is relatively new to Serbia. However, recent laws regulating the use of natural resources have enabled some basic environmental economics mechanisms.

The current Environmental Protection Act in Serbia adopted the "user pays" principle and introduced fees for the use of natural resources and some ecological services. Other laws, such as the Water Act and the Forest Act, also regulate payments for the use of natural resources. Two ministries share the responsibility of water management in Serbia: the Ministry of the Environment (ME) and the Ministry of Agriculture, Forestry and Water Management (MAFWM). Fund for Water is not an institution, but a separate budget item in the national budget. It was established in 2010 by the Law on Waters. Six types of charges go into the Fund for Water. Financial plan for water management activities for 2011. shows that the highest financial part is directed to: management of water courses and flood control (32,93\%). Some of the important characteristics of a PES schemes that are absent in existing financial mechanisms in Serbia are: explicit internalization of environmental costs; transparent pricing system; clear indications of purpose of charges; control of use of generated income; monitoring the efficiency of financed conservational measures.
\end{abstract}

Keywords: PES, stakeholders, Serbia

\section{INTRODUCTION}

Global policies have started to acknowledge the importance of ecosystem services and to incorporate them in economic systems during last decade. Payment for Ecosystem Services (PES) is becoming increasingly popular as a way to manage ecosystems using economic incentives (Kosoy and Corbera, 2010). Previous experience with incentive-based approaches suggests it is unlikely a PES approach will always be able to simultaneously improve livelihoods, increase ecosystem services, and reduce costs (Jack et al., 2008).

\footnotetext{
${ }^{1}$ Ljiljana Keča (corresponding author: ljiljana.keca@sfb.bg.ac.rs), Aleksandar Marković, University of Belgrade, Faculty of Forestry, Belgrade, SERBIA

Paper is presented on Green Room Sessions - International Conference, Podgorica 2018

Notes: The authors declare that they have no conflicts of interest. Authorship Form signed online.
} 
Numerous international programs promote PES such as: UNEP, CBD, IUCN. These laws do not regulate the investment of collected fees (Farley and Costanza, 2010).

Provisions for the use of these funds are defined broadly, and they do not explicitly ensure the financing of conservation initiatives. Classification of ecosystem services is based on Millennium Ecosystem Assessment (Bennett et al., 2009). The PES concept is relatively new to Serbia. Different Laws define "user's pays" (Vatn, 2010) for natural resources: Law of Forests (2011a), Law on Environmental Protection (2004), Law on Waters (2010). There are 4 main group of funds connected to PES in Serbia. They have different functions:

a. Fund for environmental protection - funding for activities in the area of preservation, sustainable use, protection and advancement of the environment, as well as in the area of energy efficiency and use of renewable energy sources (2009, 2011b). b. Fund for waters - Ministry of Environmental Protection is in charge for water pollution issues and Ministry of Agriculture, Forestry and Water Protection for water use, flood prevention and technical aspects of water management. c. Fund for forests - directs funds for growth of forest coverage by reforestation; improvement of the state of coniferous plantations; conversion of coppice forests to high forests, etc. d. Charges for use of protected areas and tourism in protected areas - Article 70 of the Law on Nature Protection (2016) allow protected area managers to collect fees for different types of use of the protected areas they manage.

Water management is under the jurisdiction of the national government, which has delegated the various tasks to the Ministry of Environmental Protection, other ministries, provincial administrative bodies, agencies of local administrations, and government-held water management companies. Major administrative functions related to water management reside with Ministry of Environmental Protection, or rather the National Water Directorate attached to it. Three government-held water management companies operate in Serbia: Srbijavode (Serbia Waters), Vode Vojvodine (Waters of Vojvodina) and Beogradvode (Belgrade Waters) (2017).

There is a variety of PES schemes all around the world (350). Implementing and managing a PES scheme is demanding for all actors involved (Mahanty et al., 2013). Base is natural capital (Guerry et al., 2015), which refers to the living and nonliving components of ecosystems-other than people and what they manufacture - that contribute to the generation of goods and services of value for people. PES are direct and flexible incentive-based mechanisms, under which a user or a beneficiary of an ecosystem service makes a direct payment in cash or in kind to an individual or community whose decisions on the use of natural resources have an impact on the ecosystem service provision (Plieninger et al., 2012).

Aim of the article is to analyze financial options connected to PES in Serbia and the mail goal of the research is to discover ways of possible improvement of PES model in Serbia in the future. 


\section{MATERIAL AND METHODS}

The methods applied in this paper were selected according to the nature of the problem and the purpose of research. Because of the specificity and comprehensiveness of the problem, the various research methods are applied. The research is mainly based on a review and comparative analysis (Wunder et al., 2008) of elements in the field of forestry, nature conservation and environmental protection in Serbia.

Source of data are: Serbian Fund for Environmental Protection, Fund for waters, Fund of Forests, Databases of national parks, financial plans, and Management plans.

\section{RESULTS AND DISCUSSION}

The Fund for Environmental Protection was established by the Law on Environmental Protection (2004). A separate Law on Fund for Environmental Protection was adopted in 2009. The fund aims to secure funding for activities in the area of preservation, sustainable use, protection and advancement of the environment, as well as in the area of energy efficiency and use of renewable energy sources. Different charges are connected to different legislation acts (Table 1).

According to the Fund's report, the total revenue was nearly 4.8 billion RSD (ca. 48 million EUR) in 2010, and 4.2 billion RSD (ca. 42 million EUR) in 2011. (Sekulic, 2012) structure of the revenues is presented in the Figure 1.

Table 1. Laws connected to PES and type of charges

\begin{tabular}{l|l|}
\hline Laws, strategy, rulebooks, acts & Type of charges \\
\hline $\begin{array}{l}\text { Law on Environmental Protection } \\
\text { Law on Fund for Environmental } \\
\text { Protection }\end{array}$ & $\begin{array}{l}\text { •charge for the use and trade with wild fauna } \\
\text { and flora amount of the charge is 10\% of the } \\
\text { market value of used/traded natural goods. }\end{array}$ \\
\hline $\begin{array}{l}\text { Trade of Wild Flora and Fauna } \\
\text { Decree on Types of Pollution, } \\
\text { for Environmental Pollution and } \\
\text { Payers, Amount and Way of } \\
\text { Calculating and Collecting of } \\
\text { Charges }\end{array}$ & $\begin{array}{l}\text { •environmental pollution charges, calculated } \\
\text { by the produced ton of contaminating } \\
\text { compounds and by the type and volume of } \\
\text { vehicles with internal combustion engines }\end{array}$ \\
\hline Other & $\begin{array}{l}\text { •charge for the registration in the European } \\
\text { Eco-management and Audit Scheme (EMAS) } \\
\text { system (cca } 600 €) \text { and charges for the use of } \\
\text { fishing areas }\end{array}$ \\
\hline
\end{tabular}


The activity of the Fund for Environmental Protection has some elements of a PES scheme, because it is partly based on the "user pays" principle (Ferraro, 2011) . However, it lacks some important aspects to be considered as a comprehensive mechanism that ensures financial support for conservation of ecological services (Sekulic, 2012). Ecological services are neither explicitly mentioned nor defined;

The Fund's objectives do cover some provisioning service, but regulating and supporting services are neglected, ie. ecosystems also contribute to pollution reduction. but that is not reflected in the allocation of financial resources. Users are not well informed about what they pay for and what ecosystem services they actually use. There are no clear regulations on using the income generated, i.e. no specific conservation measures. No clear provisions on monitoring the effect of conservation measures applied are in place. Activities which are financed by the Fund for Environmental Protection are numerous: protection, preservation and improvement of the quality of air, water, soil and forests, mitigation of climate changes and ozone layer protection; rehabilitation of waste landfills, encouragement of reduction of waste creation, recycling; incentives for cleaner production; technology and products that could reduce the burden to and pollution of the environment; biodiversity and geodiversity protection and preservation; incentives for sustainable use of protected natural areas; improvement of existing and building of new infrastructure for environmental protection; incentives for use of renewable energy sources and increased energy efficiency; incentives for cleaner transport; incentives for sustainable development; development of the system of information about the environmental state, preventive and intervention measures in emergency environmental pollution, projects and programs for geological research; incentives for ecological education and raising awareness of environmental problems and sustainable development; co-financing the obligations of the Republic in relation to subsidiary measures (Sekulic, 2012).

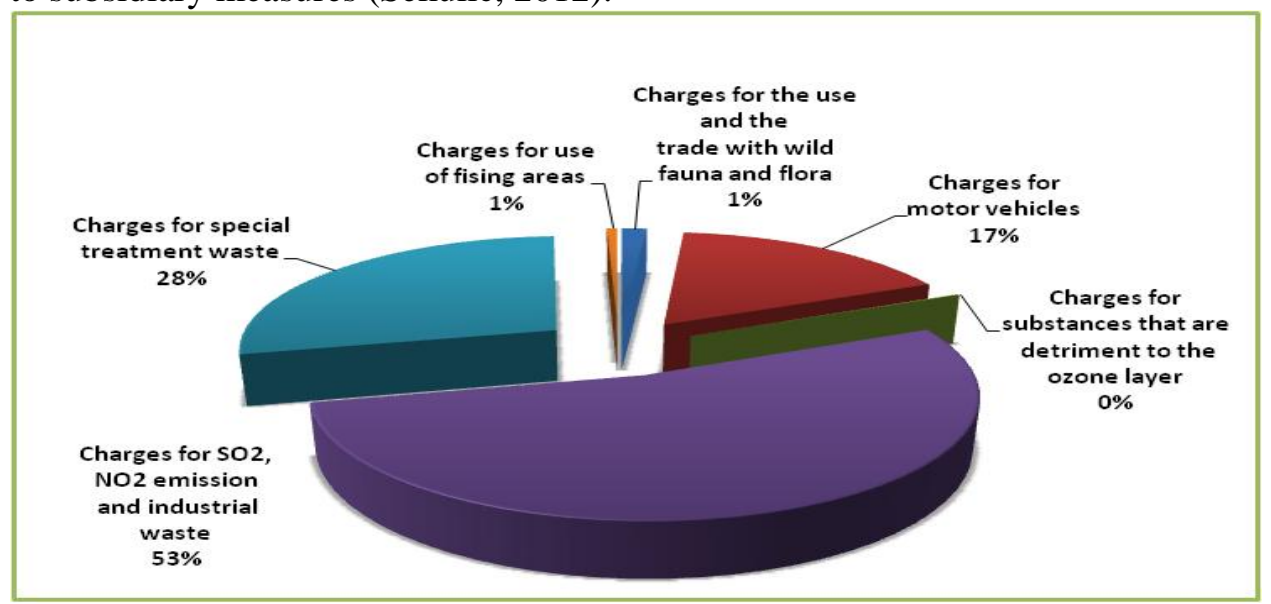

Figure 1. Structure of the revenues of the Fund of the Environmental Protection (Source: Serbian Fund for Environmental Protection) 
The annual program for 2011 defines 14 priority fields, of which 5 are related to waste management, 1 to water, air and soil protection each, 1 to nature conservation, 1 to renewable energy sources, 1 to cleaner production, 2 to education and 1 to other activities defined by law. Two ministries share the responsibility of water management in Serbia: the Ministry of the Environment Protection (MEP) and the Ministry of Agriculture, Forestry and Water Management (MAFWM).

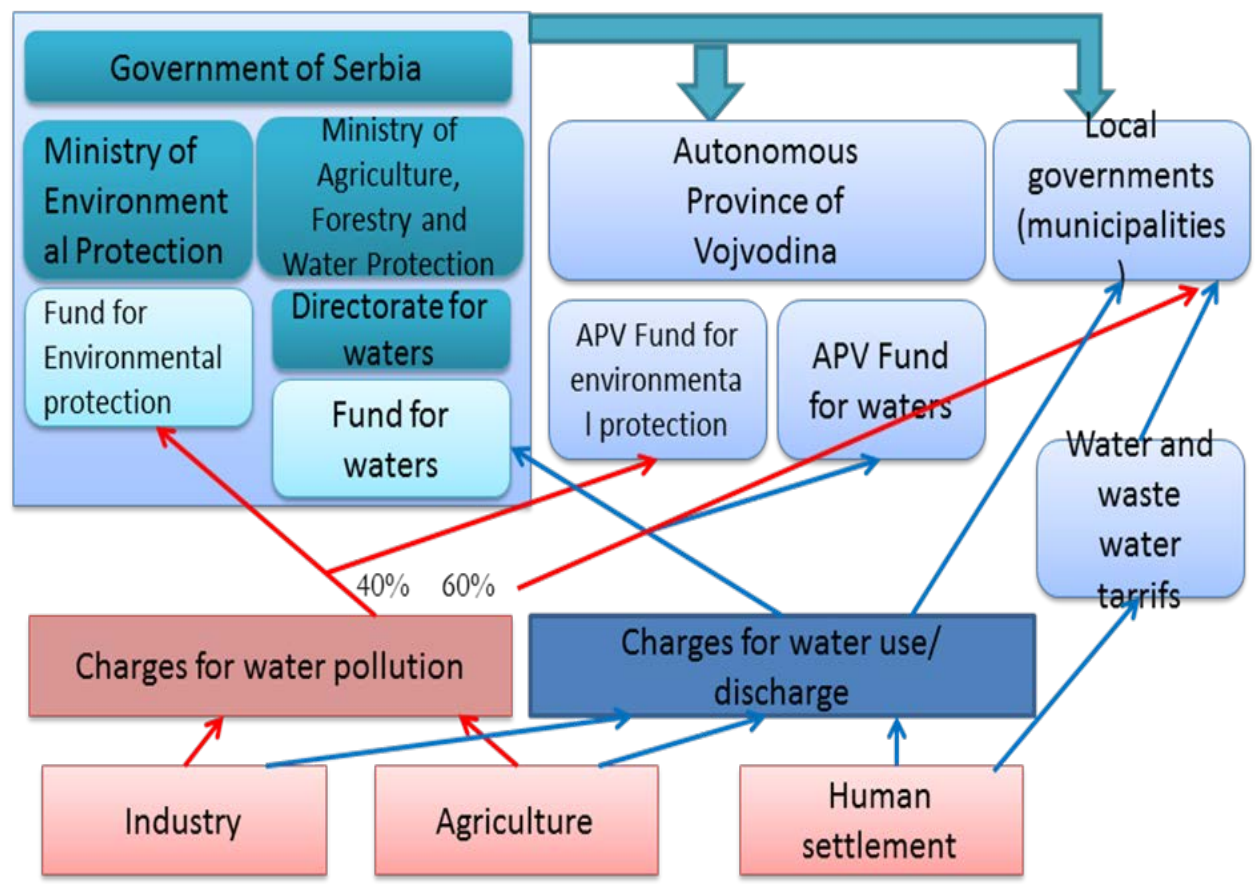

Figure 2. Structure of the revenues of the Fund of the Environmental Protection (Source: WWF, 2012)

In general, MEP is responsible for water pollution issues, while MAFWM is responsible for water use, flood prevention and for other technical aspects of water management. Six types of charges go into the Fund for Water: charge for use of water resource; charge for water discharge; charge for pollution of water; charge for drainage; charge for use of public water facilities and systems; charge for basin water management. The first three charges are fees for economic instruments related to water protection; the remaining three are water management charges. System of charges in the water management sector in Serbia is related to numerous of stakeholders (Figure 2).

Charge for use of water resources is paid for: drinking water supply (per $\mathrm{m}^{3}$ ); bottling of water $\left(\right.$ per $\mathrm{m}^{3}$ ); use of thermal waters $\left(\right.$ per $\left.\mathrm{m}^{3}\right)$; irrigation (per $\mathrm{m}^{3}$ or per ha); fisheries (per $\mathrm{m}^{3}$ or per ha); energy production in hydro power plants (per $\mathrm{kWh}$ ); other production facilities (per $\mathrm{kW}$ ); use of river sediments (per $\mathrm{m}^{3}$ of 
extracted sediment); use of "water land” for commercial purposes (per $\mathrm{m}^{2}$ or type of activities); locating a temporary floating object for commercial purposes (per $\mathrm{m}^{2}$ ); mooring and placement of floating objects (per $\mathrm{m}^{2}$ of an object) (Sekulic, 2012). Charge for water discharge is paid for discharging of waste waters in water courses, channels, lakes, accumulations or in canalization systems (Mays, 2010). In the context of PES, it is important to note that the fee for water discharge is higher in protected domains that have specific importance for water protection (van Ittersum and van Steenbergen, 2003). Charge for water pollution focuses more on the level and type of pollution than on volume of discharged water (2017). Charge for drainage every owner or user of land, infrastructure, road infrastructure or public land has to pay this charge, unless a drainage system for atmospheric waters is in place. An increase in the drainage charge will increase the pollution savings from switching technologies, but the extent will be determined by the characteristics of the crop and the technologies (Caswell et al., 1990). Charge for use of public water facilities and systems all users of public water facilities for water supply, for discharge of waste waters and for transport pay this charge. Charge for water basin management this charge is used for water course management and for flood protection (Kaštelan-Macan et al., 2007). The two charges are mutually exclusive: users who pay one are exempt from paying the other. In the context of PES schemes, it is noteworthy that managers of protected areas don't have to pay this charge. Revenues are used for water management in particular catchment areas and for drainage systems. Many such areas are natural floodplains and these revenues could be used for their restoration and management.

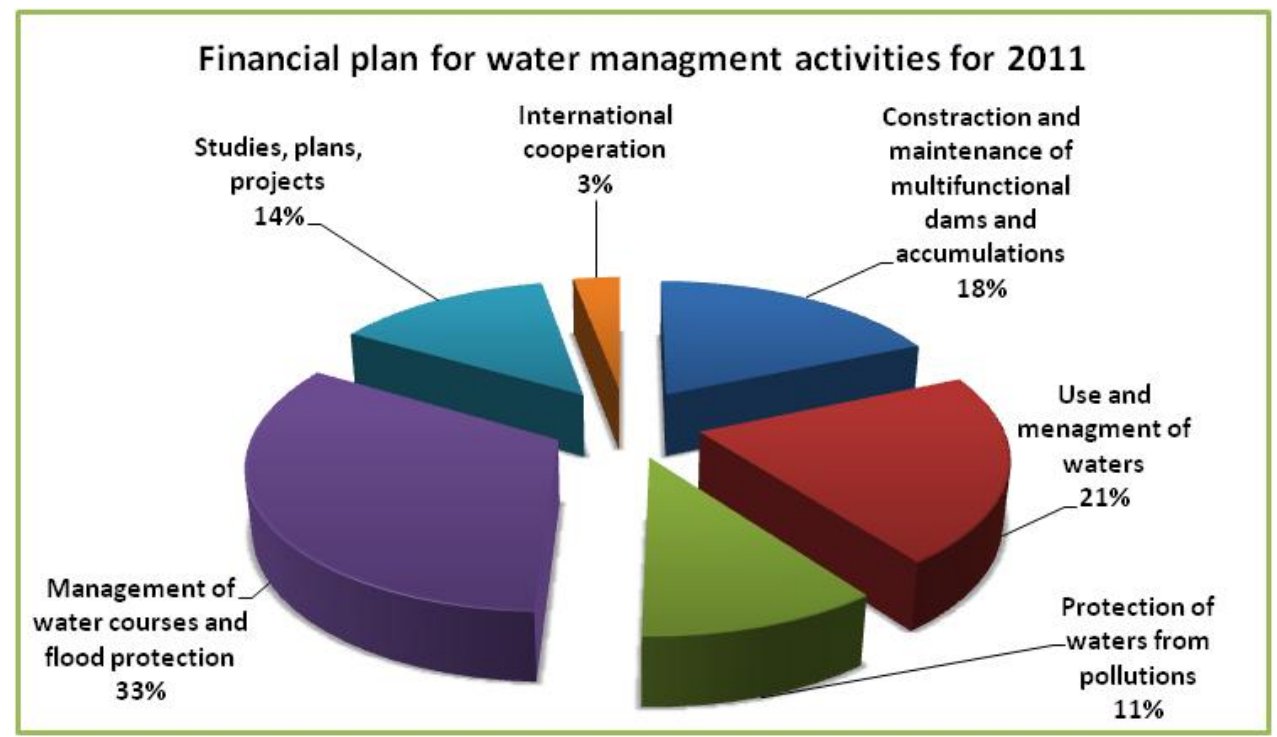

Figure 3. Financial Plan for Water management activities in 2011

(Source: WWF, 2012) 
Financial plan for water management activities shows that the majority of the financial means are in the management of water courses and flood protection and use and management of waters (Figure 3).

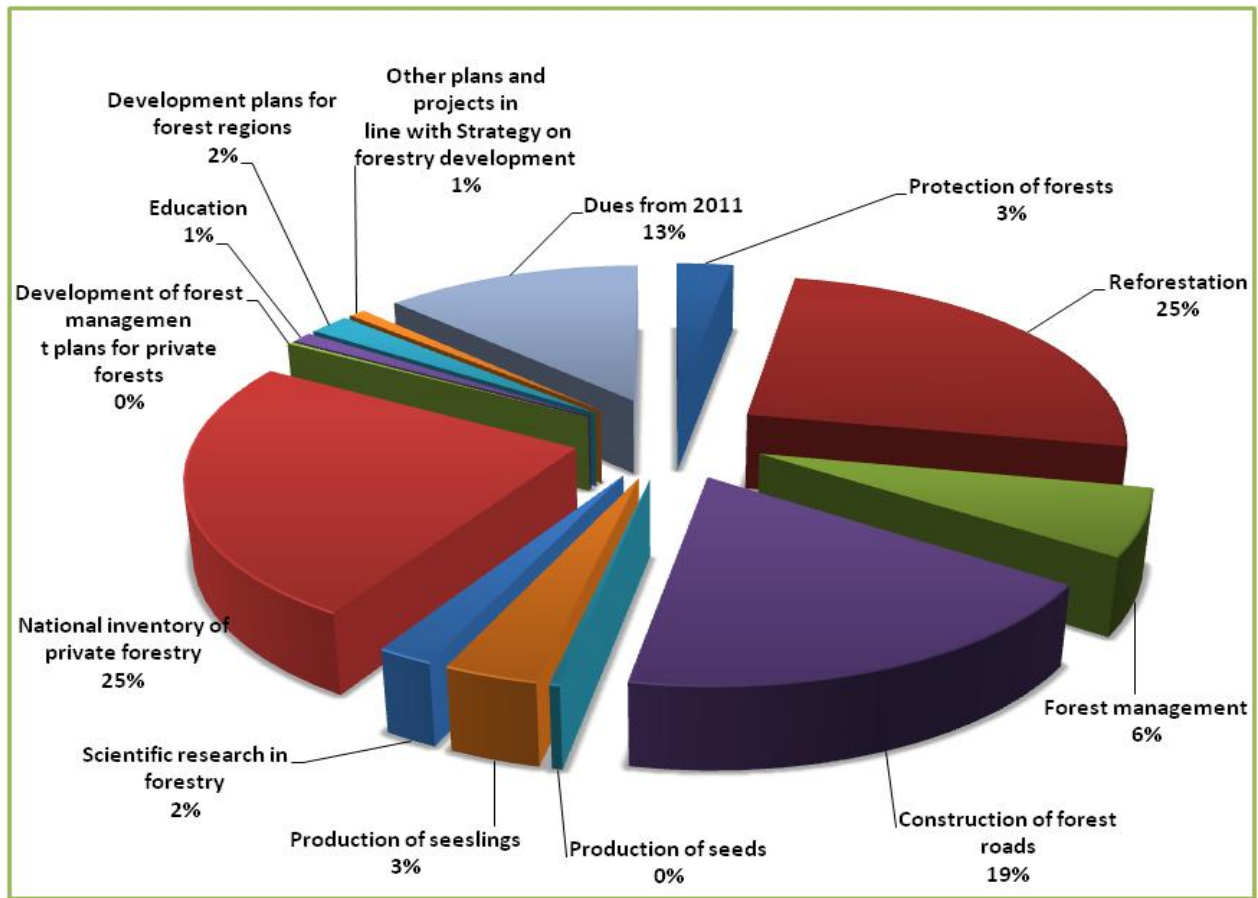

Figure 4. Financial Plan funded by the Fund of Forests in 2012 (Source: Serbian Fund of Forests, 2012)

The Fund for Forests is a separate budget item in the national budget. Fund finance the following activities: growth of forest coverage by reforestation; improvement of the state of coniferous plantations; conversion of coppice forests to high forests; production of reproductive material. The Fund's assets come from the following sources: fee for forest and forestland use; fee for protection, use and improvement of forest service's of public interest; other sources (national budget, rural development funds, donations, etc.). Every owner or user of forest pays this fee. The fee is a percentage of the total income from forest management. Forest users (public enterprises that manage public forests) pay 3\% of their total annual income, while forest owners pay 5\%. Any legal entity in Serbia, except for public enterprises established for forest and national park management, has to pay this fee equal to $0,025 \%$ of the entity's gross annual income (Lalic et al., 2011).

Although significant funds are allocated for reforestation, that is not necessarily a biodiversity friendly activity. Sometimes, valuable and biodiversity rich non-forest areas are being forested for economic reasons (extension of forest areas used for intensive timber use). Article 90 of the same law requires forest 
users and owners to assess the forest value in their forest management plans. The law defines forest value as the value of timber, land, non-timber forest products and forest functions of public interest. This article actually provides basic steps for the development of PES schemes in forestry, and it is very important that it also recognize forest functions (services) of public interest. However, there are no by-laws regarding this issue, and the lack of experience and capacities for integrated valuing of forests has stalled progress on this front. Half of the forests in Serbia are privately owned, which is a good opportunity for the development of PES schemes.

The financial plan allocates significant sum to conservation measures, such as protection, reforestation and management, also for national inventory and forest roads construction (Figure 4).

Article 70 of the Law on Nature Protection allows protected area managers to collect fees for different types of use of the protected areas they manage. The charges are set by the Decree of Closer Criteria, Manner of Calculation and Collection of Fees, as well as by protected area management decisions.

\section{CONCLUSIONS}

There are few financial schemes related to natural resources in Serbia. Currently, none of them fully complies with the concept of PES schemes, but most of them have the potential to be adapted into functional PES schemes. Most of these schemes have been in place for many years and are traditional financial mechanisms for the use of natural resources.

Characteristics which are absent in PES schemes in Serbia are: explicit internalization of environmental costs; transparent pricing system; clear indications of purpose of charges; control of use of generated income (it should be mainly used for improvement of the state of the ecosystems); monitoring the efficiency of financed conservational measures.

Some steps necessary in order to establish a PES scheme using these funds: revenues from charges for the use of flora and fauna have to be, at least partly, allocated to financing projects/measures whose explicit objective is improving the conservation state of used species and their habitats; responsible institutions (Ministry of the Environment Protection) have to define criteria for project/measures eligibility with a focus on improving the status of used species and more efficient system of control have to be established.

In the future it would be important to establish and promote charges for the use of protected area on the national level, so that all protected managers can benefit from these opportunities; establish a transparent pricing system (in agreement with users) with reference to estimated environmental costs; account for these charges separately from the rest of the budget and use the revenues for conservational measures only, as mandated by law; avoid using the revenues from these charges to finance general management costs; focus on the conservation of habitats and species, including proactive measures, such as restoration, reintroduction, repopulation, etc. 


\section{ACKNOWLEDGMENTS}

Scientific researches on the paper are financed by the COST TN 1401 CAPABAL Capacity Building in Forest Policy and Governance in Western Balkan Region.

\section{REFERENCES}

Kosoy, N., \& Corbera, E. (2010). Payments for ecosystem services as commodity fetishism. Ecological economics, 69(6), 1228-1236.

Jack, B. K., Kousky, C., \& Sims, K. R. (2008). Designing payments for ecosystem services: Lessons from previous experience with incentive-based mechanisms. Proceedings of the National Academy of Sciences.

Farley, J., \& Costanza, R. (2010). Payments for ecosystem services: from local to global. Ecological economics, 69(11), 2060-2068.

Bennett, E. M., Peterson, G. D., \& Gordon, L. J. (2009). Understanding relationships among multiple ecosystem services. Ecology letters, 12(12), 1394-1404.

Vatn, A. (2010). An institutional analysis of payments for environmental services. Ecological economics, 69(6), 1245-1252.

(2011a): Official Gazette of the Republic of Serbia no. 30/2011.

(2004): Official Gazette of the Republic of Serbia no. 135/2004

(2010): Official Gazette of the Republic of Serbia no. 30/2010.

(2011b): Official Gazette of the Republic of Serbia no. 72/2009 \& 101/2011

(2016): Official Gazette of RS, no. 36/2009, 88/2010 and 91/2010 - corr. and 14/2016

Mahanty, S., Suich, H., \& Tacconi, L. (2013). Access and benefits in payments for environmental services and implications for REDD+: Lessons from seven PES schemes. Land Use Policy, 31, 38-47.

Guerry, A. D., Polasky, S., Lubchenco, J., Chaplin-Kramer, R., Daily, G. C., Griffin, R., ... \& Feldman, M. W. (2015). Natural capital and ecosystem services informing decisions: From promise to practice. Proceedings of the National Academy of Sciences, 112(24), 7348-7355.

(2017): Water sector in Serbia, Brussels Regional Public Services (16)

Plieninger, T., Schleyer, C., Schaich, H., Ohnesorge, B., Gerdes, H., Hernández-Morcillo, M., \& Bieling, C. (2012). Mainstreaming ecosystem services through reformed European agricultural policies. Conservation Letters, 5(4), 281-288.

Wunder, S., Engel, S., \& Pagiola, S. (2008). Taking stock: A comparative analysis of payments for environmental services programs in developed and developing countries. Ecological economics, 65(4), 834-852.

Sekulic G. (2012): Analysis of PES Needs and Feasibility in Serbia,WWF, (33)

Ferraro, P. J. (2011). The future of payments for environmental services. Conservation Biology, 25(6), 1134-1138.

Mays, L. W. (2010). Water resources engineering. John Wiley \& Sons.

van Ittersum, M., \& van Steenbergen, F. (2003). Ideas for local action in water management. Global Water Partnership.

Caswell, M., Lichtenberg, E., \& Zilberman, D. (1990). The effects of pricing policies on water conservation and drainage. American journal of agricultural economics, 72(4), 883-890.

Kaštelan-Macan, M., Ahel, M., Horvat, A. J., Jabučar, D., \& Jovančić, P. (2007). Water resources and waste water management in Bosnia and Herzegovina, Croatia and the State Union of Serbia and Montenegro. Water Policy, 9(3), 319-343.

Lalic, D., Popovski, K., Gecevska, V., Vasilevska, S. P., \& Tesic, Z. (2011). Analysis of the opportunities and challenges for renewable energy market in the Western Balkan countries. Renewable and Sustainable Energy Reviews, 15(6), 3187-3195. 